九州大学学術情報リポジトリ

Kyushu University Institutional Repository

\title{
Successive Protoplast Transformation of Bacillus subtilis by Plasmid DNA under Low Concentration of Lysozyme
}

Hara, Toshio

Microbial Genetic Division, Institute of Genetic Resources, Faculty of Agriculture, Kyushu University

Lee, Jin Tae

Microbial Genetic Division, Institute of Genetic Resources, Faculty of Agriculture, Kyushu University

Prana, Titik Kriswidarti

Laboratory of Food Technology, Department of Food Science and Technology, Faculty of Agriculture, Kyushu University

Akamatsu, Takashi

Department of Applied Microbiolgy and Technology, Kumamoto Institute of Technology

他

https://doi.org/10.5109/23964

出版情報 : 九州大学大学院農学研究院紀要. 36 (1/2)，pp.23-28，1991-10. Kyushu University バージョン：

権利関係 : 


\title{
Successive Protoplast Transformation of Bacillus subtilis by Plasmid DNA under Low Concentration of Lysozyme
}

\author{
Toshio Hara' *, Jin Tae Lee', Titik Kriswidarti Prana ${ }^{2}$, \\ Takashi Akamatsu ${ }^{3}$, Yusaku Fujio ${ }^{2}$ and Seiya Ogata \\ ${ }^{1}$ Microbial Genetic Division, Institute of Genetic Resources, \\ ${ }^{2}$ Laboratory of Food Technology, Department of Food Science \& \\ Technology, Faculty of Agriculture, Kyushu University, \\ Hakozaki, Higashi-ku, Fukuoka 812, Japan and ${ }^{3}$ Department of \\ Applied Microbiolgy and Technology, Kumamoto Institute of \\ Technology, Ikeda, Kumamoto 860, Japan
}

(Received April 9, 1991)

\begin{abstract}
A protoplast transformation system for Bacillus subtilis AC819 with pUB110plasmid DNA under high pressure of kanamycin $(100 \mu \mathrm{g} / \mathrm{ml})$ has been developed by using extremely low concentration of lysozyme, $2.5 \mu \mathrm{g} / \mathrm{ml}$, with a high regeneration efficiency of protoplasts. The optimum transformation of protoplasts was achieved under the conditions as follows : lysozyme concentration, $2.5 \mu \mathrm{g} / \mathrm{ml}$; incubation period with lysozyme at $40.5 \mathrm{C}$, for $20 \mathrm{~min}$; intermediate cultivation, at $30 \mathrm{C}$ for $90 \mathrm{~min}$ without shaking ; incubation temperature for regeneration, at $30 \mathrm{C}$. A response of kanamycin-resistant transformants to the number of protoplasts reached $1.9 \times 10^{4}$ per $370 \mathrm{ng}$ of plasmid DNA, which corresponds to $100 \%$ per regenerants, and its efficiency was $10^{3}$ fold higher than that of competent cell transformation.
\end{abstract}

\section{INTRODUCTION}

Protoplast transformation was established by Chang and Cohen (1979), and a gene transfer system in bacilli has been well documented (Brown and Carlton, 1980 ; Vorobjeva et al., 1980 ; Imanaka et al., 1981 ; Martin et al., 1981). Successful protoplast transformation of bacilli requires at least both efficient utilization of DNA in the transformation process and efficient regeneration of protoplasts. We found the most limiting step in this system was the regeneration of protoplasted cells, which occurs the formation of L-form colonies and subsequently the regeneration of those L-form colonies to normal bacilli-form cells (Akamatsu and Sekiguchi, 1989). In these steps, however, surface of protoplasted cells generated with lysozyme might have an influence on the regeneration efficiency of protoplasts. Lysozyme was used for protoplast formation at varied concentrations as follows ;2 mg/ml (Chang and Cohen, 1979), 20 $\mathrm{mg} / \mathrm{ml}$ (Bakhiet and Stahly, 1985) in Bacillus subtilis, $2 \mathrm{mg} / \mathrm{ml}$ in B. licheniformis (Jensen and Hulett, 1989), and $1 \mathrm{mg} / \mathrm{ml}$ in B. megaterium (Tatsubo et al., 1990). After 20 min with lysozyme, cell walls of bacilli were completely removed under such a high enzyme concentration, and the protoplasted cells were appeared. It is, therefore, necessary for the protoplasted cells to be overlaid with the top agar for obtaining a high frequency of regeneration. The most efficient transformation systems were

*Corresponding author 
established for strains of B. stearothermophilus (Imanaka et al., 1982 ; Liao et al., 1986). In these transformation systems, protoplasts of B. stearothermophilus were prepared with the final concentration of $1 \mu \mathrm{g} / \mathrm{ml}$ in order to improve regeneration efficiency.

We attempted to improve the regeneration efficiency of protoplasts, which were prepared with a low concentration of lysozyme, and to achieve the high frequency transformation of $B$. subtilis with a low DNA concentration. In this report, we describe the development of a protoplast transformation system for B. subtilis.

\section{MATERIALS AND METHODS}

\section{Bacterial strains and plasmid}

Bacillus subtilis strain AC819 (hisH, strA, tet-1, smo-1) was used for all transformation procedures. Plasmid pUB110 carrying a kanamycin (Km)-resistant gene was used for transformation.

\section{Media and materials}

For bacterial growth, Penassay antibiotics medium 3 (PAB, Difco) was used. Sucrose-magnesium-malate (SMM) buffer of Wyrick and Rogers (1973) was the same as follows ; SMM buffer contained 0.5 M sucrose, $0.02 \mathrm{M}$ maleic acid (pH6.5) and 0.02 $\mathrm{M} \mathrm{MgCl}_{2}$. For protoplast regeneration, Trypticase Soy Broth (TSB, BBL) medium containing 3\% TSB, $0.02 \mathrm{M} \mathrm{MgCl}_{2}, 0.3 \mathrm{M}$ sodium succinate $(\mathrm{pH} 7.3), 0.1 \mathrm{wt} \%$ bovine serum albumin (Nacalai Tesque, Inc., Kyoto, Japan) and 2\% Bacto agar (Difco) was used with or without $100 \mu \mathrm{g} / \mathrm{ml}$ of kanamycin.

\section{Preparation of plasmid DNA}

Plasmid DNA was prepared by $\mathrm{CsCl}$-ethidium bromide equilibrium density gradient centrifugation as described previously (Hara et al., 1983).

\section{Protoplasts Transformation}

(i) Protoplast formation

Protoplasts were prepared according to the slightly modified method described by Akamatsu and Sekiguchi (1983). A $0.1 \mathrm{ml}$ of preculture of B. subtilis AC819 was inoculated into $25 \mathrm{ml}$ of $\mathrm{PAB}$ medium in an Erlenmyer flask to cultivate the bacterial cells at $37 \mathrm{C}$ for $3 \mathrm{hr}$ with shaking. The culture was centrifuged $(5,000 \mathrm{rpm}$ at $4 \mathrm{C}$, for $2 \mathrm{~min}$ ) and the bacteria'were suspended in $4 \mathrm{ml}$ of SMM supplemented with $2.5 \mathrm{mg}$ per $\mathrm{ml}$ of lysozyme (Sigma Chem. Co.). The mixture was gently shaken (80 strokes per $\mathrm{min}$ ) in $50 \mathrm{ml}$ Erlenmyer flask at $40.5 \mathrm{C}$ for $20 \mathrm{~min}$, after that added $10 \mathrm{ml}$ of SMM, centrifuged $(5,000 \mathrm{rpm}$ at $4 \mathrm{C}$ for $3 \mathrm{~min})$ and resuspended in $500 \mu \mathrm{l}$ of SMM buffer.

(ii) Polyethylene glycol (PEG)-induced transformation

A $250 \mu 1$ of the protoplast suspension, after adding plasmid DNA pUB110, was gently added $750 \mu \mathrm{l}$ of $80 \%$ polyethylene glycol (\# 4000, Nakarai Chemical Co., Kyoto). The mixture was kept on ice for $2 \mathrm{~min}$, and then vigorously added $5 \mathrm{ml}$ of $\mathrm{SMM}$, further added $15 \mathrm{ml}$ of SMM and centrifuged (5,000 rpm at $4 \mathrm{C}$ for $5 \mathrm{~min})$.

(iii) Phenotypic expression

The pellet suspended in $1 \mathrm{ml}$ of TSB medium was incubated at $30 \mathrm{C}$ for $90 \mathrm{~min}$ without shaking. 
(iv) Regeneration of protoplasts and selection of transformants

A $100 \mu 1$ volume of the protoplasts sample was spread onto TSB $2 \%$-agar plate containing kanamycin $(100 \mu \mathrm{g} / \mathrm{ml})$ for direct selection of transformants without overlaying. Transformation frequency was scored after incubation of the protoplasts at 30 C for 2 days.

\section{Competent cells transformation}

Competent cells were prepared as described by Bott and Wilson (1967) and transformation was carried out as described previously (Aumayr et al., 1981).

\section{RESULTS AND DISCUSSION}

\section{Optimal conditions for protoplast transformation}

The protoplast transformation procedures established for B. subtilis (Chang and Cohen, 1979) were applicable for B.licheniformis (Jensen and Hulett, 1989) and $B$. megaterium (Takubo et al., 1990). Imanaka et al. (1982) was succeeded to achieve the protoplast transformation for thermophilic bacilli with a low lysozyme concentration. In order to further maximize the efficiency of our transformation procedure, we

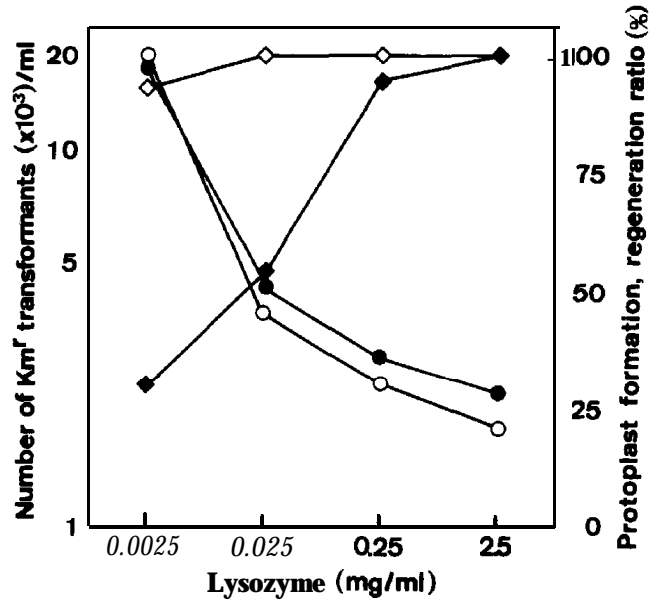

Fig. 1. Effect of lysozyme concentration on protoplast transformation.

Culture was treated with various concentrations of lysozyme for preparation of protoplasts at $40.5 \mathrm{C}$ for $20 \mathrm{~min}$. The protoplasts contacted with pUB110 in polyethylene glycol were incubated at $30 \mathrm{C}$ for $90 \mathrm{~min}$ without shaking for phenotypic expression, and spread onto TSB agar plates with and without kanamycin. The colonies regenerated on TSB agar plates containing kanamycin were counted as Km' transformants. Number of protoplasts were estimated as round-shape cells with microscopic observation or by taking the number of colonies regenerated on sodium succinate- and $\mathrm{MgCl}_{2}$-free TSB agar plates after adding water from the number of colonies grown on complete TSB agar plates. Symbols: - number of Km' transformants; $\bigcirc$, regeneration ratio ; $\diamond$, protoplast formation ratio with microscopic observation; $\diamond$, protoplast formation ratio by plating on TSB agar plate. 
investigated the effects of various concentrations of lysozyme on protoplast transformation (Fig. 1). The number of protoplasts were estimated by taking the number of colonies regenerated on sodium succinate- and $\mathrm{MgCl}_{2}$-free TSB agar plates after adding water from the number of colonies grown on a complete TSB agar plates. As shown in Fig. 1, at $2.5 \mu \mathrm{g} / \mathrm{ml}$ of lysozyme, the highest efficiency of protoplast transformation was achieved and $1.9 \times 10^{4}-\mathrm{Km}^{\mathrm{r}}$ transformants were obtained. The significant difference in protoplast formation ratio was not detected in the series of lysozyme concentrations used, whereas a regeneration ratio of protoplasts was greatly differred depend on used lysozyme concentration. The lower concentration of lysozyme is, the higher the regeneration ratio of protoplasts under the same experimental conditions. The number of regenerated colonies from protoplasts treated with $2.5 \mu \mathrm{g} / \mathrm{ml}$ of lysozyme was $1.9 \times 10^{4}$ per $\mathrm{ml}$, which corresponds to $100 \%$ as a regeneration ratio. The high efficiency of regeneration of protoplasts might be resulted from the states of surface of protoplasted cells treated with lysozyme. It seems that some remained pieces of cell wall might act as a primer for the cell wall synthesis on regeneration of protoplasted cells. Subsequently, a higher efficiency of protoplast transformation might be achieved. In fact, the use of $2.5 \mu \mathrm{g} / \mathrm{ml}$ of lysozyme let to form less than 35 $\%$ as a round-shape bacilli by microscopic observation.

Figure 2 shows the effects of DNA concentrations on protoplast transformation. The transformation ability at different concentrations of plasmid DNA for B. subtilis shows a sensitivity potentially capable of detecting less than $37 \mathrm{pg}$ of DNA. The relatively high transformation efficiency, $3 \times 10^{3} \mathrm{Km}$ ' transformants, of protoplasted cells with a low concentration of lysozyme, $2.5 \mu \mathrm{g} / \mathrm{ml}$, was achieved with extremely lower DNA concentration. It is noted that, furthermore, the transformation efficiency of protoplasted cells with $2.5 \mu \mathrm{g} / \mathrm{ml}$ of lysozyme was much higher than that with 2.5

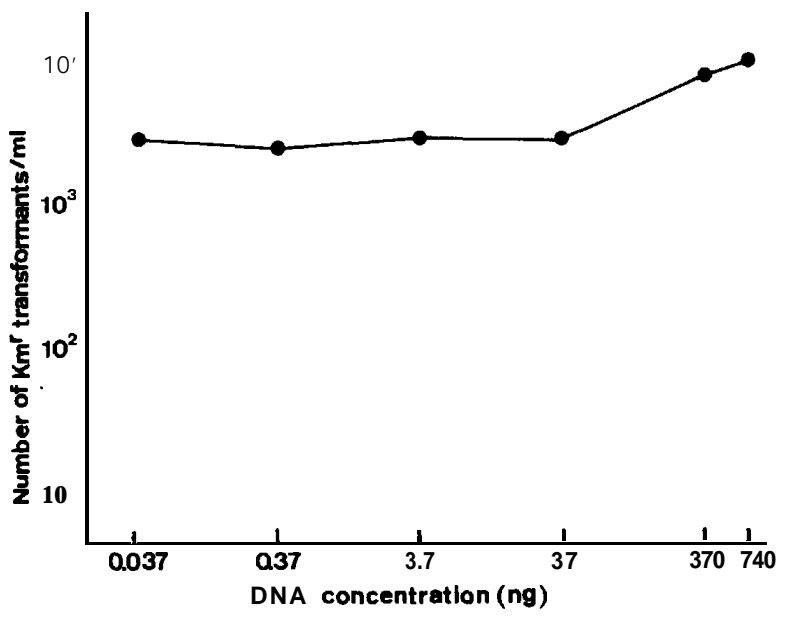

Fig. 2. Effect of DNA concentration on transformation efficiency.

Protoplasts were transformed with $370 \mathrm{ng}$ of pUB110 as described above, and $0.1 \mathrm{ml}$ of aliquots were plated on TSB regeneration plates containing kanamycin $(100 \mu / \mathrm{ml})$. Number of Km' transformants was caluculated by multiplying the dilution factor for each plate and indicated the number of Km' per ml. 
$\mathrm{mg} / \mathrm{ml}$ of the enzyme, whereas, above $370 \mathrm{ng} / \mathrm{ml}$ of plasmid DNA, the transformation efficiency with $2.5 \mathrm{mg} / \mathrm{ml}$ of lysozyme was slightly lower than that with $2.5 \mu \mathrm{g} / \mathrm{ml}$ of enzyme. These results indicate that this transformation system can be used for shotgun cloning experiments.

\section{Comparison of transformation efficiency between protoplasts and competent c e 1 l s}

The results of transformation experiments were summarized in Table 1 . The final DNA concentration in the transformation mixtures was $370 \mathrm{ng} / \mathrm{ml}$. Competent cells transformation was carried out according to the method described previously (Aumayr et al., 1981). The transformation frequency of competent cells was $3.6 \times 10^{-5}$ per 370 ng of plasmid DNA, and the number of Km' transformants was $4.0 \times 10$. The highest efficiency of protoplast transformation was performed with protoplasted cells with 2.5 $\mu \mathrm{g} / \mathrm{ml}$ of lysozyme, and the number of $\mathrm{Km}$ ' transformants reached $1.9 \mathrm{X} 10^{4}$, which corresponds to $1.3 \times 10^{-1}$ as frequency. Its efficiency was $10^{3}$ fold higher than that of competent cells transformation. The transformation efficiency of B.megaterium protoplasts with pUB110 was $8.5 \times 10^{4}$ per $\mu \mathrm{g}$ of plasmid pUB110. This value was found to be considerably higher even at selective pressure of neomycin $(100 \mu \mathrm{g} / \mathrm{ml})$, compared with our obtained result $(1.9 \times 10$ " Km' transformants $)$ under high selective pressure at $100 \mu \mathrm{g} / \mathrm{ml}$ of kanamycin. Recently, Takubo et al. (1990) reported that spore-spheroplast transformation of $B$. megaterium was developed and that the number of $\mathrm{Km}$ ' transformants was $1.1 \times 10^{4}$, which corresponds to $1.1 \times 10^{-5}$ as frequency.

In summary, it is quite important for successful protoplast transformation to achieve high regeneration ratio of protoplasted cells with lysozyme, and, consequently, to obtain efficient utilization of DNA in the transformation process.

Table 1 Transformation frequencies of protoplasts and competent cells

\begin{tabular}{|c|c|c|c|c|c|c|c|}
\hline \multirow{2}{*}{$\begin{array}{l}\text { Transformation } \\
\text { system }\end{array}$} & \multirow{2}{*}{$\begin{array}{l}\text { Lysozyme } \\
\text { conc. }\end{array}$} & \multicolumn{2}{|c|}{$\begin{array}{l}\text { Percent of } \\
\text { formation }\end{array}$} & \multirow{2}{*}{$\begin{array}{l}\text { Percent of } \\
\text { regeneration }\end{array}$} & \multirow{2}{*}{$\begin{array}{l}\text { Conc. of } \\
\mathrm{Km} \\
(\mu \mathrm{g} / \mathrm{ml})\end{array}$} & \multirow{2}{*}{$\begin{array}{l}\text { No. of } \\
\mathrm{Km} \text {, }\end{array}$} & \multirow{2}{*}{$\begin{array}{l}\text { Frequency } \\
\text { of } \mathrm{Km} \text { ' }\end{array}$} \\
\hline & & round & $\mathrm{TSB}^{\mathrm{b}}$ & & & & \\
\hline \multirow[t]{2}{*}{ Protoplasts } & $2.5 \mu \mathrm{g} / \mathrm{ml}$ & $25.1 \%$ & $92.0 \%$ & $100 \%$ & 100 & $1.9 \times 10^{4}$ & $1.3 \times 10^{-1}$ \\
\hline & $2.5 \mathrm{mg} / \mathrm{ml}$ & $99.9 \%$ & $99.9 \%$ & $20.8 \%$ & 100 & $1.4 \times 10^{3}$ & $1.0 \times 10^{-2}$ \\
\hline \multirow[t]{3}{*}{ Competent cells ${ }^{\mathrm{d}}$} & & & & & 5 & $3.5 \times 10^{2}$ & $3.2 \times 10^{-4}$ \\
\hline & & & - & & 25 & $1.5 \times 10^{\prime}$ & $1.4 \times 10^{-4}$ \\
\hline & & & & & 100 & $4.0 \times 10$ & $3.6 \times 10^{-5}$ \\
\hline
\end{tabular}

DNA used for protoplasts and competent cell transformation was $370 \mathrm{ng} / \mathrm{ml}$ of plasmid pUB110. "The number of protoplasts formed was counted with microscopic observation.

"The number of protoplasts was estimated by counting the colonies on TSB and sodium succinateand $\mathrm{MgCl}_{2}$-free TSB agar plates.

'The number of regenerated cells was determined by plating the nontransformed protoplasts on regeneration medium without kanamycin. In this experiments, the number of total cells per $\mathrm{ml}$ was $1.5 \times 10^{7}$.

${ }^{\mathrm{d}}$ The number of total cells per $\mathrm{ml}$ was $1.1 \mathrm{X} 10^{8}$. 


\section{REFERENCES}

Akamatsu, T. and Sekiguchi J. 1983 Selection methods in bacilli for recombinants and transformants of intra- and interspecific fused protoplasts. Arch. Microbiol., 134 : 303-308

Akamatsu, T. and Sekiguchi, J. 1987 Characterization of chromosome and plasmid transformation in Bacillus subtilis using gently lysed protoplasts. Arch. Microbiol., 146, 353-357

Aumayr, A., T. Hara and S. Ueda 1981 Transformation of Bacillus subtilis in polyglutamate production by deoxyribonucleic acid from B. natto.J. Gen. Appl. Microbiol., 27 : 115-123

Bakhikt, N. and Stahly, D. P. 1985 Studies on transfection and transformation of protoplasts of Bacillus larvae, Bacillus subtilis, and Bacillus popilliae. Appl.Environ. Microbiol., 49:577-581

Bott, K. and Wilson, G. A. 1967 Development of competence in the Bacillus subtilis transformation system. J. Bactetiol., $94: 562-570$

Brown, B. J. and Carlton, B.C. 1980 Plasmid-mediated transformation in Bacillus megaterium. J. Bacteriol., $142: 508-512$

Chang, S. and Cohen, S. N. 1979 High frequency transformation of Bacillus subtilis protoplasts. Mol. Gen. Genet., $168: 111-115$

Hara, T. Zhang, J. R. and Ueda, S. 1983 Identification of plasmids linked with polyglutamate production in Bacillus subtilis (natto). J. Gen. Appl Microbiol., 29 : 345-354

Imanaka, T., Tanaka, T., Tsunekawa, H., and Aiba, S. 1981 Cloning of the genes for penicillinase, penP and penI, of Bacillus licheniformis in some vector plasmids and their expression in Escherichia coli, Bacillus subtilis, and Bacillus licheniformis. J. Bacteriol., 147: 776-786

Imanaka, T., Fujii, M., Aramori, I. and Aiba, S. 1982 Transformation of Bacillus stearothermophilus with plasmid DNA and characterization of shuttle vector plasmids between Bacillus stearothermo. philus and Bacillus subtilis. J. Bactetiol., 149 : $824-830$

Jensen, K. K. and Hulett, F. M. 1989 Protoplast transformation of Bacillus licheniformis MC14. J. Gen. Microbiol., $135: 2283-2287$

Liao, H., McKenzie, T., and Hageman, R. 1986 Isolation of a thermostable enzyme variant by cloning and selection in a thermophile. Proc. Natl. Acad.Sci.U.S. A., $83: 576-580$

Martin, P. A. W., Lohr, J. R., and Dean, D. H. 1981 Transformation of Bacillus thuringiensis protoplasts by plasmid deoxyribonucleic acid. J. Bacteriol., $145: 980-983$

Takubo, Y., Nishikawa, J., Tani, K., Nishihara, T., and Kondo, M. 1990 Spore-spheroplast transformation of Bacillus megaterium. Nihon Saikingaku Zatsushi, $45: 841-843$

Vorobjeva, I. P., khmel, I. A., and Alfldi, L. 1980 Transformation of Bacillus megaterium protoplasts by plasmid DNA. FEMS Microbiol. Lett., $7: 261-263$

Wu, L. and Welker, N. E. 1989 Protoplast transformation of Bacillus stearothermophilus NUB36 by plasmid DNA. J. Gen. Microbial., 135 :1315-1324

Wyrick, P. B. and Rogers, H. J. 1973 Isolation and characterization of cell wall-defective variants of Bacillus subtilis. J. Bacteriol., $116: 456-465$ 